\title{
The Development of Learner's Autonomy by the Way of the Formation of Social Intelligence
}

\section{Розвиток автономії студента засобами формування його соціального інтелекту}

\author{
Eduard Ivashkevych
}

Dr. in Psychology, Professor, Rivne State University of the Humanities, Rivne (Ukraine)

ORCID ID: https://orcid.org/0000-0003-0376-4615

Researcher ID: http://www.researcherid.com/rid/V-8872-2018

E-mail: ivashkevych.e@gmail.com

\section{Едуард Івашкевич}

Доктор психологічних наук, професор, Рівненський державний гуманітарний університет, м. Рівне (Україна)

\section{Liana Onufriieva}

Dr. in Psychology, Professor, Head of the Department of General and Applied Psychology, Kamianets-Podilskyi National Ivan Ohiienko University, Kamianets-Podilskyi (Ukraine)

ORCID ID: https://orcid.org/0000-0003-2442-4601

Researcher ID: http://www.researcherid.com/rid/R-5598-2018

Scopus Author ID: 57214601047

E-mail: kpnu_lab_ps@ukr.net

\section{Ліана Онуфрієва}

Доктор психологічних наук, професор, завідувач кафедри загальної та практичної психології, Кам'янець-Подільський національний університет імені Івана Огієнка, м. Кам'янець-Подільський (Україна)

Address for correspondence, e-mail: kpnu_lab_ps@ukr.net Copyright: (C) Ivashkevych Eduard, Onufriieva Liana

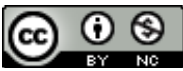

The article is licensed under CC BY-NC 4.0 International (https://creativecommons.org/licenses/by-nc/4.0/)

(C) Ivashkevych Eduard, Onufriieva Liana DOI (article): https://doi.org/10.32626/2227-6246.2021-51.09-32 
DOI: https://doi.org/10.32626/2227-6246.2021-51

2021. випуск 51

The contribution of the author: Ivashkevych E. $-50 \%$, Onufriieva L. $-50 \%$. Авторський внесок: Івашкевич Е. - 50\%, Онуфрієва Л. - 50\%.

\section{ABSTRACT}

The aim of the article is to characterize students' autonomous behavior and propose the ways of its formation by the way of stimulating the growth of structural components of social intelligence of students.

The following theoretical methods of the research were used to solve the tasks formulated in the article: a categorical method, structural and functional methods, the methods of the analysis, systematization, modeling, generalization. Also in our research we used empirical methods, such as statement study and molding experiment.

The results of the research. We emphasize that the social intelligence of the teacher contains cognitive, empathic and mnemonic aspects. Elements (or scripts, frames, concepts) of the empathic aspect of social intelligence are the content of specific educated perceptions of the images of reality, which can be perceived directly, and those that arise in the memories and the imagination of the person. The specific function of the empathic aspect of social intelligence is that empathic frames, scripts and concepts which give emotional products of the intellectual activity, a peculiar picture of the world that is formed as a result of the activity of social intelligence, which causes the world to appear to the subject as existing in metacognitive sphere. It is substantiated that it makes no sense to talk about the existence of emotional intelligence, because that meaning, which is invested by many researchers in this concept, is fixed precisely in the empathic aspect of social intelligence. Although the empathic aspect of social intelligence is not perceived by the teacher, and in the opinion of the authors of this article it provides awareness of the emotionally-expressive and empathic sides of objects and subjects in the process of interpersonal interaction.

We believe that social intelligence, clearly, includes declarative and operational (procedural) knowledge that the individual uses in a real life to interpret events, to create plans and predict both the actions of everyday life and professional situations. These ideas, personal memories and rules of interpretation constitute the cognitive aspect of social intelligence. In turn, the mnemonic aspect fills the experience gained by a person, while the empathic capabilities of the subject have the aim actualizing the mechanisms of anticipation in solving various problems of social life.

C Ivashkevych Eduard, Onufriieva Liana

DOI (article): https://doi.org/10.32626/2227-6246.2021-51.09-32 
DOI: https://doi.org/10.32626/2227-6246.2021-51

2021. ВИПУСК 51

Conclusions. Thus, the cognitive aspect of social intelligence includes a set of fairly stable knowledge, assessments, rules for interpreting events, people's behavior, their relationships, etc., based on the formed system of interpretations at the microstructural and macrostructural levels. The microstructure of the cognitive aspect of social intelligence is determined by the functions of the latter, such as the cognitive-evaluative one, on which the competent processing is depended and the evaluation of information perceived by the subject; prognostic function, on the basis of which the planning and forecasting of the development of interpersonal interactions are carried out; communicative functions, which ensure the effectiveness of the actual communicative process (this function is associated with adequate perception and understanding of the partner in communication); reflexive function, which is reflected directly by the person's self-knowledge. In turn, the macrostructure of the cognitive aspect of social intelligence is manifested in the individual's attitude to himself / herself as a value, value-semantic position to interpersonal relationships, as well as by the actualization of motivational and value orientations of the individual, axiological attitude by him / her to professional and other activities. By the way of the developing of learner's autonomy we stimulated the development of the cognitive aspect of social intelligence.

Key words: learner's autonomy, autonomous behavior, social intelligence, the cognitive aspect of social intelligence, motivational orientations, value orientations, axiological attitude.

\section{Introduction}

There are many good reasons why to foster autonomous behavior. From the broad perspective, living in a democratic society encourages and demands autonomous behavior. Making decisions, taking responsibilities are the everyday aspects of life. And schools should reflect this reality to be able to lead children towards autonomous way of life.

When taking psychological factors into account, autonomy «is a basic human need. It is nourished by, and in turn nourishes, our intrinsic motivation, our proactive interest in the world around us» (Little, 2006: 2). This leads us to the solution of one of the gravest issues of the day that is called passivity. As G. Kavaliauskienë (2002: 1) implies, the passive

(c) Ivashkevych Eduard, Onufriieva Liana DOI (article): https://doi.org/10.32626/2227-6246.2021-51.09-32 
role that learners assume in language learning, prevents them from developing and fulfilling their potential. Therefore, what we are speaking about is a philosopher's stone of teaching itself. How to help our learners become successful? Fostering autonomous behaviour is a prerequisite of success. According to D. Dafei (2007: 1) we found out in his research: "The results of the study indicate that the students' English proficiency was significantly and positively related to their learner autonomy». D. Little (2006) finds the connections between learner autonomy and language proficiency as well: «Precisely because autonomous learners are motivated and reflective learners, their learning is efficient and effective (conversely, all learning is likely to succeed to the extent that the learner is autonomous). And the efficiency and effectiveness of the autonomous learner means that the knowledge and skills acquired in the classroom can be applied to situations that arise outside the classroom» (Little, 2006: 2).

We (Little, 1996: 18) call active knowledge like D. Little describes as skills applied outside the classroom. The opposite is «school knowledge», something has been acquired only to an extent to be able to answer the teacher's questions. Transforming the school knowledge into the action knowledge is seen as one of the crucial parts of the teacher's practice. D. Little believes that the development of learner's autonomy is essential to be succeed in this task (Little, 1996; 2006).

The aim of our article is to characterize students' autonomous behavior and propose the ways of its formation by the way of stimulating the growth of structural components of social intelligence of students.

\section{Methods of the research}

The following theoretical methods of the research were used to solve the tasks formulated in the article: a categorical method, structural and functional methods, the methods of the analysis, systematization, modeling, generalization. Also (c) Ivashkevych Eduard, Onufriieva Liana

DOI (article): https://doi.org/10.32626/2227-6246.2021-51.09-32 
DOI: https://doi.org/10.32626/2227-6246.2021-51 2021. випуск 51

in our research we used empirical methods, such as statement study and molding experiment.

\section{Results and their discussion}

An interesting reason for promoting learner's autonomy is put forward by L. Dickinson (1994). She sees the situation as a kind of bipolar. Either we foster autonomy or we foster dependence: "As teachers we do not want to be implicated in the development of teacher dependent adult students; we see the achievement of independence in learning as desirable, allowing the student to pursue his own learning objectives in ways and at times which most suit him, and so we adopt the additional teaching objective to teach the student how to learn» (Dickinson, 1994: 2).

M. Hořínek (2007) adds a kind of pragmatic and economic argument for incorporating autonomy training into the classroom. As he summarizes the ideas of Benson and Crabbe, the society simply does not have enough financial resources «to provide the level of personal instruction needed by all its members in every area of learning» (Hořínek, 2007: 8).

So far, the development, fostering or promoting learner's autonomy seem to be the cornerstone of successful learning. Nevertheless, it has to be taken into account that autonomy itself is not a guarantee of successful learning. "Autonomous learners may make the wrong decisions, and may put a lot of energy into doing rather useless things» (Dickinson, 1994: 5). L. Dickinson gives the example of a learner who decided to memorize a dictionary. After three years he got to the middle of «C». Even if he demonstrated features of totally autonomous learner, he can hardly be described as a successful person. He knew little about Grammar, and his vocabulary has been to be restricted to A, B and C. As L. Dickinson (1994) concludes: "What we are really concerned with is "informed" autonomy. That is, learners who are sufficiently knowledgeable about language learning to make approximately correct deci-

(c) Ivashkevych Eduard, Onufriieva Liana DOI (article): https://doi.org/10.32626/2227-6246.2021-51.09-32 
sions about their own learning. It is unreasonable to expect that encouraging a student to become more independent, or autonomous, in acquiring language skills will bring about any tangible changes. Learners have to be taught the skill "how to learn». Learning this skill is a slow process and can only be perfected in a step-by step manner» (Dickinson, 1994: 5).

In this extract of the article the reasons for fostering autonomy were listed as well as the cautions that have to be taken into consideration when conducting the learner training in autonomy. Also we will learn what such training may look like and how different authors deal with fostering autonomous behavior of their learners. In such a way we will explore possibilities of fostering learner's autonomy in the classroom. As this paper deals with the action research within the classroom we will not take into account the self-access, independent modes of learning without a teacher.

There are six different perspectives to look at fostering learner's autonomy (Гончарук \& Онуфрієва, 2018). These are resource-based, technology-based, learner-based, classroombased, curriculum-based and teacher-based approaches.

While the resource and technology based approaches represent a kind of creating opportunities for learners to take control over their learning then the learner-based approach equips the learner with the abilities to take this control (Benson, 2001: 142). The primary goal of all the learner-based approaches is to help learners become more successful by teaching them how to learn. This includes behavioural and psychological changes that enable the learners to take greater control over their learning as well as awareness of available learning strategies and their own learning styles. However, P. Benson (2001: 150) warns against acquiring a mere set of techniques without abilities to apply them flexibly and critically. At this point P. Benson (2001) concludes: «Reflective training models appear to be more effective in fostering autonomy because they integrate (c) Ivashkevych Eduard, Onufriieva Liana

DOI (article): https://doi.org/10.32626/2227-6246.2021-51.09-32 
these three aspects of control and allow the learners to develop awareness of the appropriateness of strategies to the overall self-direction of their learning» (Benson, 2001: 150).

Classroom-based approach focuses on creating possibilities for learners to make decisions regarding management of their learning since this empowering of the learner is seen as a crucial factor in the learner's autonomy training. As P. Benson (2001: 161) summarizes the most of the research results show that the learners are able to "take a degree of control over the assessment and planning of classroom learning" if they are given a chance to do so. This capacity seems to develop better in a classroom with the teacher's support than outside the classroom.

Curriculum-based approach takes the learners control over the language content to a higher level. P. Benson (2001: 163) mentions the term "Process Syllabus» that represents the ideas of curriculum based approach. This term was developed in 1980's in the connection with communicative approach. According to the Process Syllabus the content of learning should not be predetermined but emerge in the classroom through collaborative activity with the teacher.

Teacher-based approaches to fostering learner's autonomy focus on changes of the traditional roles of a teacher and a learner. The professional development and teacher education is seen as the crucial aspect of these changes. Only autonomous teacher can lead children to autonomous learning. "In order to create spaces for learners to exercise their autonomy, teachers must recognise and assert their own" (Benson, 2001: 173) According to P. Benson (2001: 171-176), teacher's dedication to the ideas of autonomy as well as his / her professional skills are fundamental to gain the success. As the issue of the roles of a teacher and a learner is highly important it will be dealt with in details in our further researches.

Although P. Benson (2001) classifies these categories separately, he concludes that «it seems likely that it [learner auto-

(c) Ivashkevych Eduard, Onufriieva Liana DOI (article): https://doi.org/10.32626/2227-6246.2021-51.09-32 
DOI: https://doi.org/10.32626/2227-6246.2021-51

2021. випуск 51

nomy] will be fostered most effectively through a combination of approaches» (Benson, 2001: 178).

As we have seen, P. Benson (2001: 116-173) looks at the approaches to fostering autonomy on a kind of general level. However, there are various authors, offering their own positions and worked out step by step procedures.

D. Little (1996) influenced by Leni Dam's (1990) action research, developed three pedagogical principles to be followed when attempting to foster learner autonomy. These are: empowering the learner, learner reflection and appropriate language use. Some other scientists (Mykhalchuk \& Kryshevych, 2019) distinguish among organizational, procedural, and cognitive autonomy support and their high or low levels.

D. Nunan (2003) presents his autonomy levels of implementation. He goes gradually from building learners' Awareness through Involvement, Intervention, and Creation to his final stage where learners become teachers and researchers. So, D. Nunan (2003: 195-204) developed these levels into a particular nine-step program of the implementation of autonomy in the classroom. As he points out the steps should be implemented sequentially, although some of them may and do overlap and allow simultaneous action. Since this instructive program was chosen as the core of the action research in the practical part of this paper it will be dealt with in details here. Although, particular activities and procedures having been used at the lessons are going to be described in our further researches.

Step one is making instructional goal clear to learners. This relatively uncontroversial step should help learners to «be involved in selecting their own goals and content» (Nunan, 2003: 197). As D. Nunan (2003: 197) reports even young learners were able to participate positively in selecting their own content and procedures. Afterwards, they were more willing to accept the responsibility for their learning.

C Ivashkevych Eduard, Onufriieva Liana

DOI (article): https://doi.org/10.32626/2227-6246.2021-51.09-32 
Step two involves learners into creating their own goals. D. Nunan (2003) is rather concise at this point of view and gives only the example of learners at higher education carrying out action meetings regularly to participate on the design of the course of studying.

Step three is encouraging learners to use the target language outside the classroom. This time the Nunan's example is relevant to the topic of this paper concerning some age group of learners. He describes a teacher eliciting all possible ways of improving learners' English outside the classroom. The final, elicited recommendations are very explicit and straightforward such as using a mirror for pronunciation practice.

In step four learners' awareness of learning processes should be raised. By this step, D. Nunan (2003: 199) implements strategy training into a course. He proposes to start with clarifying the strategies underlying the classroom practice. Explicitness again plays one of the main roles.

During the fifth stage of Nunan's program the learners should identify their preferred learning styles and strategies. D. Nunan (2003: 200) considers this step highly important as the preferences of the learners might be "often markedly at odds with the content and the methodology that they were exposed in the class». This finding should entail radical changes in both, content and methodology of the course. Appropriate activities addressing different types of learners should be implemented.

Step six should encourage learner's choice. The teacher may either give options for students to choose if there may be a class vote or probably such activities as learning centers may be included. At this stage Nunan's aim is making learners sensitized to the idea of making choices. After getting used to making such choices the learners may proceed to a higher level, when skills are stimulated and they are going to work at first.

Step seven allows learners to generate their own task by modifying and adapting class tasks. D. Nunan (2003: 202) sees

(C) Ivashkevych Eduard, Onufriieva Liana DOI (article): https://doi.org/10.32626/2227-6246.2021-51.09-32 
DOI: https://doi.org/10.32626/2227-6246.2021-51 2021. випУСК 51

this stage as a preliminary step for teaching learners to create their tasks completely by their own. As he points out no special material design skills have to be needed. On the contrary, he started with the texts without comprehension questions. These ones were made by groups of learners and then answered and discussed.

Step eight may seem unrealistic; however, D. Nunan (2003: 202) suggests that learners should become teachers. He even describes this stage as of "paramount importance». As we know, people remember over ninety percent of the subject matter they are supposed to teach. Considering this fact, learners teaching learners may bring a lot of benefits. "Being an «expert» on a topic noticeably increased self-esteem, and getting more confident week by week gave [the learners] a feeling of genuine progress» (Nunan, 2003: 202).

As the final ninth step in his program D. Nunan (2003: 203) encourages teachers to educate learners to become researchers. He gives the example of the research in the United States conducted by educationally disadvantaged children gathering and interpreting data concerning the language they have been encountered outside the classroom.

In this article we have listed different approaches to or perspectives of fostering learner's autonomy. The core ninestep program was described in general terms. Particular activities addressing each of the steps will be described in details in further our researches.

We predicted that to stimulate the development of learner's autonomy and motivation the students must have a high level of social intelligence. In such a way let us describe a structure of social intelligence, that'll help us to investigate the empirical research of social intelligence of students of high educational establishments.

We emphasize that the social intelligence of the teacher contains cognitive, empathic and mnemonic aspects. Elements (or scripts, frames, concepts) of the empathic aspect of social (c) Ivashkevych Eduard, Onufriieva Liana

DOI (article): https://doi.org/10.32626/2227-6246.2021-51.09-32 
DOI: https://doi.org/10.32626/2227-6246.2021-51

2021. випуСК 51

intelligence are the content of specific educated perceptions of the images of reality, which can be perceived directly, and those that arise in the memories and the imagination of the person. The specific function of the empathic aspect of social intelligence is that empathic frames, scripts and concepts which give emotional products of the intellectual activity, a peculiar picture of the world that is formed as a result of the activity of social intelligence, which causes the world to appear to the subject as existing in metacognitive sphere. It is substantiated that it makes no sense to talk about the existence of emotional intelligence, because that meaning, which is invested by many researchers in this concept, is fixed precisely in the empathic aspect of social intelligence. Although the empathic aspect of social intelligence is not perceived by the teacher, and in the opinion of the authors of this article it provides awareness of the emotionally-expressive and empathic sides of objects and subjects in the process of interpersonal interaction.

We believe that social intelligence, clearly, includes declarative and operational (procedural) knowledge that the individual uses in a real life to interpret events, to create plans and predict both the actions of everyday life and professional situations. These ideas, personal memories and rules of interpretation constitute the cognitive aspect of social intelligence. In turn, the mnemonic aspect fills the experience gained by a person, while the empathic capabilities of the subject have the aim actualizing the mechanisms of anticipation in solving various problems of social life.

So, in our experiment (2019-2021) participated the students from different courses of Rivne State University of the Humanities (groups E1, K1 - from the $1^{\text {st }}$ course; groups E2, $\mathrm{K} 2$ - from the $2^{\mathrm{d}}$ course; groups E3, K3 - from the $3^{\mathrm{d}}$ course), and students of the speciality 053 Psychology (groups Ps1B16, Ps1-B17, Ps1-B18) of Kamianets-Podilskyi National Ivan Ohiienko University.

(C) Ivashkevych Eduard, Onufriieva Liana DOI (article): https://doi.org/10.32626/2227-6246.2021-51.09-32 
DOI: https://doi.org/10.32626/2227-6246.2021-51

$\frac{2}{0}$

\begin{tabular}{|c|c|c|c|c|c|c|c|c|c|c|c|c|}
\hline ח2 & $\begin{array}{l}+1 \\
\text { ¿ }\end{array}$ & $\stackrel{\vec{N}}{\sim}+1$ & $\stackrel{\infty}{\dot{C}}$ & $\stackrel{\leftrightarrow}{\infty}+1$ & $\begin{array}{l}0 \\
\stackrel{0}{-} \\
\dot{0}\end{array}$ & 무 & & & $\begin{array}{l}m \\
\ddot{r}+1 \\
\dot{\gamma}\end{array}$ & 1 & 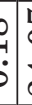 & 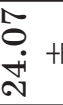 \\
\hline$\stackrel{N}{*}$ & छ ⿷ & $\underset{\infty}{\not}+1$ & 年 & $\stackrel{\infty}{\sim}+1$ & $\begin{array}{l}+ \\
\stackrel{+}{0} \\
\dot{0}\end{array}$ & $\begin{array}{l}\stackrel{N}{7} \\
\stackrel{0}{0}\end{array}$ & & & $\stackrel{r}{\dot{r}}+1$ & 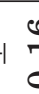 & & $\stackrel{+}{+}+4$ \\
\hline
\end{tabular}

ชु

동

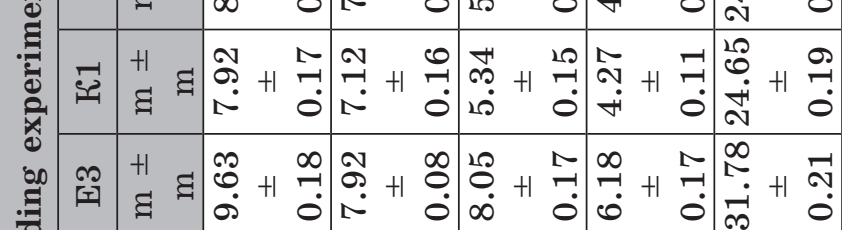

.ृ

$\stackrel{0}{+1}$

क्ष

䓪

4

త్

का

Ð

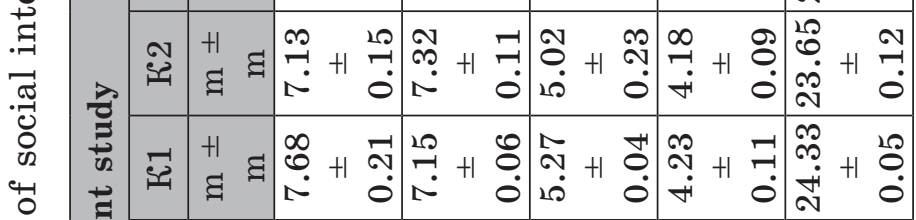

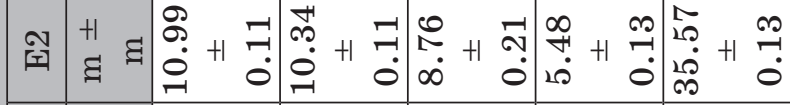

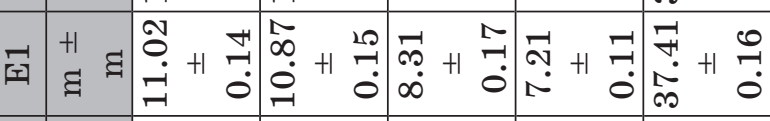

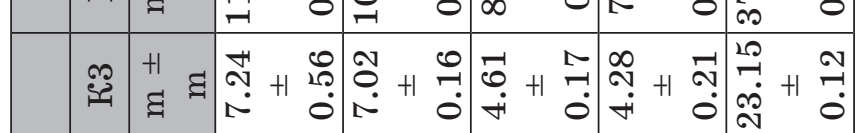

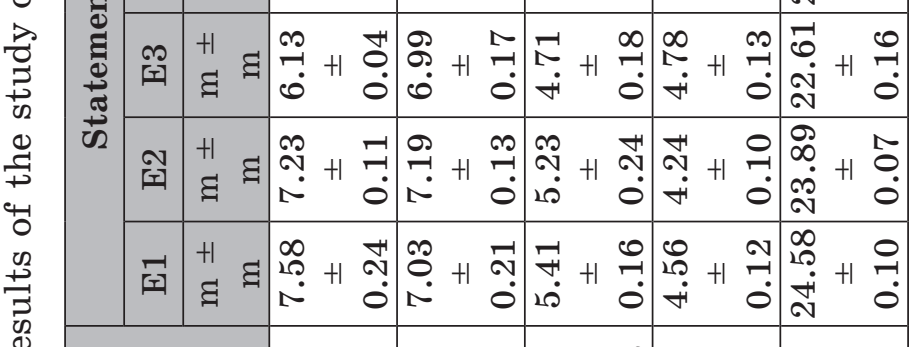

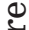

릴

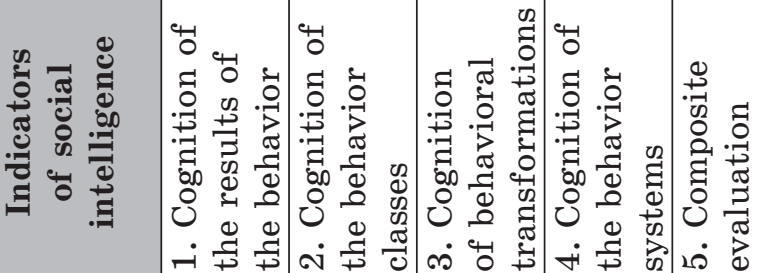

(C) Ivashkevych Eduard, Onufriieva Liana

DOI (article): https://doi.org/10.32626/2227-6246.2021-51.09-32 
According to the results obtained by the «Method of measuring social intelligence» by J. Guilford and M. O'Sullivan (see Table 1), the indicators of students of the experimental group on the $1^{\text {st }}$ subtest «knowledge of behavioral results» (social forecasting) are significantly higher compared to two others (the average score on this subtest of students of the experimental group ranges from 9.63 to 11.02). According to the selected average value, the indicators for the $1^{\text {st }}$ subtest of students of experimental groups correspond to the standard score of 4 . This indicates that after the introduction of the experimental program of future teachers of groups E1, E2, E3 above average is developed knowledge of behavioral outcomes, the ability to predict consequences behavior of people in a certain situation, predict what will happen next. The competence of «forecasting the results of social interaction" has the lowest level of the development in group E3 (average score is 9,63), and the highest level is in groups E2 and E1 (average score is 10,99 and 11,02 , respectively).

In control groups the indicators on the first subtest of social intelligence did not change and it was compared with the statement studied (in such a way: 7.68 - in $\mathrm{K} 1,7.13$ - in $\mathrm{K} 2,7.23$ - in K3; in the formative experiment: 7.92 - in $\mathrm{K} 1$, 8.11 - in K2, 7.21 - in K3), which indicates that, in fact, social intelligence is not formed during the students' studying at the university without the purposeful influence of teachers. Social intelligence is a relatively stable characteristic, which, however, can be formed during a person's life, during the course of personally significant events for a given person, for quite long periods of time and so on. The formation of social intelligence, in particular, its individual components, is possible as a result of purposeful, specially organized influence, which was implemented by us in experimental groups through the use of the program to facilitate the formation of social intelligence of a future teacher. During the formative experiment students of groups E1, E2, E3 realized their opportunities and personal

(c) Ivashkevych Eduard, Onufriieva Liana DOI (article): https://doi.org/10.32626/2227-6246.2021-51.09-32 
potentials, the development of their professionally significant qualities, interests, abilities, feelings, relationships, the formation of valuable orientations, creating a favorable psychological climate for the professional development in studied groups, providing timely assistance in solving their own problems and expanding opportunities for self-development of the individual, which, in turn, facilitated the formation of social intelligence of future teachers.

According to the second subtest, the average value of indicators of students of experimental groups is ranged from 7.92 to 10.87 , which corresponds to a standard score of 4 (the result is higher than the average sample rate). This indicates the level of knowledge of above-average behavioral classes, such as the ability to logically generalize, to identify common essential features in various nonverbal human reactions. These abilities (highlighted in the above structure of social intelligence as social intuition) have the highest level of the development of students of groups E1 and E2 (the average score is 10.87 and 10.34, respectively). At the same time, the least pronounced «ability to understand nonverbal speech" is for students of group E3 (average score is 7.92), as well as for students of control groups $(7.12$ - in $\mathrm{K} 1,7.18$ - in $\mathrm{K} 2,7.32$ - in $\mathrm{K} 3$ at the end of the molding experiment).

Describing the data on the $3^{\text {rd }}$ subtest, we can say about the remarkable dynamics in the development of basic components in the structure of social intelligence from the beginning of the observational study, and to the final slice of the formative experiment. The lowest indicator according to this subtest was diagnosed for students of group E3 (the average value is 8.05 points), while for students of groups E1 and E2 the indicators are slightly higher (8.31 points and 8.76 points, respectively). Students in the control groups were not diagnosed with progressive minds, and a slight increase in results is statistically insignificant at 5\% confidence level according to the Student's t-criterion. This indicates that all respondents in the control (c) Ivashkevych Eduard, Onufriieva Liana

DOI (article): https://doi.org/10.32626/2227-6246.2021-51.09-32 
groups have the level of knowledge of behavioral transformation (the ability to understand the change in the meaning of such verbal human reactions depending on the context of the situation that caused them) below average, which also indicates the effectiveness of our facilitative program of the development of social intelligence of future teachers.

\section{Conclusions}

Thus, the cognitive aspect of social intelligence includes a set of fairly stable knowledge, assessments, rules for interpreting events, people's behavior, their relationships, etc., based on the formed system of interpretations at the microstructural and macrostructural levels. The microstructure of the cognitive aspect of social intelligence is determined by the functions of the latter, such as the cognitive-evaluative one, on which the competent processing is depended and the evaluation of information perceived by the subject; prognostic function, on the basis of which the planning and forecasting of the development of interpersonal interactions are carried out; communicative functions, which ensure the effectiveness of the actual communicative process (this function is associated with adequate perception and understanding of the partner in communication); reflexive function, which is reflected directly by the person's self-knowledge. In turn, the macrostructure of the cognitive aspect of social intelligence is manifested in the individual's attitude to himself / herself as a value, value-semantic position to interpersonal relationships, as well as by the actualization of motivational and value orientations of the individual, axiological attitude by him / her to professional and other activities. By the way of the developing of learner's autonomy we stimulated the development of the cognitive aspect of social intelligence.

The source of social intelligence at the microstructural level is the continuous updating of the functions listed by us. The result of their integration can be considered a set of sub-

(c) Ivashkevych Eduard, Onufriieva Liana DOI (article): https://doi.org/10.32626/2227-6246.2021-51.09-32 
jective scales that allow the subject to navigate the features of interpersonal interaction, to recognize and adequately assess the behavior of other individuals. One of the main results of high-level social intelligence will be the presence of the individual of subjective statistics of different modalities. It is a space of subjective psychosemantic scales, symbols of nonverbal behavior, norms of language production, etc.

The task of social intelligence at the macrostructural level is to provide opportunities to assess themselves and other people as individuals. In this case, the value orientations of the individual may not coincide with generally accepted social norms and even conflicts with them, but there is always a society and its specific representatives, in which the individual worldview, personal values and meanings will find their support.

We consider the criteria for the productive functioning of the student's social intelligence as a successful solution to human social non-standard (including - original) tasks, as well as the success of a specialist in the implementation of pedagogical activities. The first involves the mandatory functioning of the decision-making mechanism. The mechanism of decision-making, as well as other functional mechanisms of social intelligence (the mechanism of decentralization, the mechanism of intellectual initiation, reflexive mechanisms, etc.) are proved by us (Mykhalchuk \& Ivashkevych, 2018), which, above all, are predetermined by individual cognition, for example, attention, imagination, perception, memory, thinking, etc., can be understood by a teacher, but may not be realized, and then it is about automatism of functional mechanisms of social intelligence. In the field of mnemonic experience (the mnemonic aspect of social intelligence) conscious experiences are accompanied by a sense of subjective evidence of what is happening. It is precisely in the case of the explicit existence of such experiences that the subject is able to give himself / herself a report on his / her own experience. Confirmation of «subjective awareness" is a psychological concept that is widely used in scien(c) Ivashkevych Eduard, Onufriieva Liana

DOI (article): https://doi.org/10.32626/2227-6246.2021-51.09-32 
tific research: «direct experience», "personally significant experience», "professionally significant experience», "subjective experience», etc. The term «awareness» will denote exclusively the ended result, the integral psychic product of active intellectual activity. In other words, awareness is the result of our research, in particular, the social intelligence of the person. The concept of "awareness" is empirical, but, unlike other empirical concepts used in psychology, is not partial. This is the so-called "complex" concept, which denotes a wide range of empirical phenomena and categories that relate to different cognitive spheres of the person, for example, to the sensory, perceptual, mental spheres of representation and human motor activity. Therefore, the concept of «awareness» is equally appropriate to refer to the facts of awareness of tactile or acoustic influence, and to name the result of reproduction of previously learned information, and, for example, to state the fact of visual representation of any object. Understanding, of course, can have its own specificity, depending on the nature of intellectual activity. Thus, awareness during the perception of oral speech, of course, differs from the perception of the solution found in the non-standard social task. However, if we are talking about such complex phenomenon as social intelligence, then as a rule, any fact that is perceived by a person is the result of unconscious intellectual activity. This activity, in turn, is carried out with the aid of well-known functional mechanisms, one of which is the mechanism for making $a$ socially balanced solution. All this in a great degree helps to form the learner's autonomy.

\section{Literature}

Гончарук Наталія, Онуфрієва Ліана. Психологічний аналіз рівнів побудови комунікативних дій. Psycholinguistics. Психолінгвістика. Психолингвистика: Зб. наук. праць ДВНЗ «Переяслав-Хлельницький пед. ун-т ілені Григорія Сковороди». Переяслав-Хмельницький : ФОП Домбровська Я. М., 2018. Вип. 24 (1). С. 97-117. DOI 10.31470/2309-1797-2018-24-1-97-117.

(C) Ivashkevych Eduard, Onufriieva Liana DOI (article): https://doi.org/10.32626/2227-6246.2021-51.09-32 
DOI: https://doi.org/10.32626/2227-6246.2021-51

Benson, P. (2001). Teaching and Researching Autonomy in Language Learning. Harlow : Longman. 565 p.

Dafei, D. (2007). An Exploration of the Relationship Between Learner Autonomy and English Proficiency. Retrieved September 27, 2007. URL : http://www.asian-efl-journal.com/pta_Nov_07_dd.pdf?origin =publication_detail.

Dam, L. (1990). Learner Autonomy in Practice: An experiment in learning and teaching. Autonomy in Language Learning, I, 35-42. Gathercole (Ed.). Great Britain : Centre for Information on Language Teaching and Research.

Dickinson, L. (1994). Learner autonomy: what, how and why? In: Autonomy in Language Learning (1st ed.). Porto Alegre : Universidade Federal do Rio Grande do Sul. P. 2-12.

Hoř́nek, M. (2007). A closer look at learner autonomy - a qualitative study. (Diploma thesis). Retrieved August 2, 2007. URL : http:// is.muni.cz/th/12319/ff_m/thesis.pdf.

Kavaliauskiene, G. (2002). Three Activities to Promote Learner's Autonomy. The Internet TESL Journal, VIII, (7). Retrieved July 4, 2002. URL : http://iteslj.org/Techniques/Kavaliauskiene-Autonomy/.

Little, D. (1996). Constructing a theory of learner autonomy: Some steps along the way. Retrieved August 27, 1996. URL : http://archive. ecml.at/mtp2/ELP_TT/ELP_TT_CDROM/DM_layout/Reference $\%$ 20Materials/English/David \% 20Little \% 20Constructing $\% 20 a \% 20$ Theory $\%$ 20of $\%$ 20Learner $\%$ 20Autonomy.pdf.

Little, D. (2006). Learner autonomy: Drawing together the threads of self-assessment, goal-setting and reflection. Retrieved August 27, 2006. URL : http://archive.ecml.at/mtp2/ELP_TT/results/DM_ layout/ 00_10/06/06Supplementarytext.pdf.

Mykhalchuk, Nataliia, \& Ivashkevych, Eduard. Psycholinguistic features of the development of social intelligence of the teacher. Psycholinguistics. Психолінгвістика. Психолингвистика: Зб. наук. праць ДВНЗ «Переяслав-Хмельницький пед. ун-т імені Григорія Сковороди». Переяслав-Хмельницький : ФОП Домбровська Я. М., 2018. Вип. 23 (1). С. 242-257. DOI https://doi.org/10.5281/zenodo. 1211618 (ISSN 2415-3397, Index Copernicus, Web of Science).

Mykhalchuk, Nataliia, \& Kryshevych, Olga. The peculiarities of the perception and understanding of Sonnets written by W. Shakespeare by the students of the Faculty of Foreign Languages. Psycholinguistics. Психолінгвістика. Психолингвистика: збірник наукових праць. Серія: Психологія. Переяслав-Хмельницький : ФОП Домбровська Я. М., 2019. Вип. 26 (1). С. 265-285. DOI 10.31470/23091797-2019-26-1-265-285.

C Ivashkevych Eduard, Onufriieva Liana

DOI (article): https://doi.org/10.32626/2227-6246.2021-51.09-32 
Nunan, D. (2003). Nine steps to learner autonomy. Retrieved June 20, 2003. URL : http://www.andrasprak.su.se/polopoly_fs/1.84007. 1333707257!/menu/standard/file/200 3_11_Nunan_eng.pdf.

\section{References}

Honcharuck, Nataliia, \& Onufriieva, Liana (2018). Psykholohichnyi analiz rivniv pobudovy komunikatyvnykh dii [Psychological analysis of levels of communicative actions' constructing]. Psykholinhvistyka. Psikholingvistika. Psycholinguistics: Zb. nauk. prats DVNZ «Pereiaslav-Khmelnytskyi ped. un-t imeni Hryhoriia Skovorody» - Psycholinguistics. Psycholinguistics. Psycholinguistics: Collection of Scientific Papers of Pereiaslav-Khmelnytskyi Hryhorii Skovoroda Pedagogical University, 24 (1), 97-117. Pereiaslav-Khmelnytskyi : FOP Dombrovska Ya. M. DOI 10.31470/2309-1797-2018-24-1-97-117 [in Ukrainian].

Benson, P. (2001). Teaching and Researching Autonomy in Language Learning. Harlow : Longman.

Dafei, D. (2007). An Exploration of the Relationship between Learner Autonomy and English Proficiency. Retrieved September 27. Retrieved from http://www.asian-efl-journal.com/pta_Nov_07_dd.pdf ?origin=publication_detail.

Dam, L. (1990). Learner Autonomy in Practice: An experiment in learning and teaching. Gathercole (Ed.). Autonomy in Language Learning, I, 35-42. Great Britain : Centre for Information on Language Teaching and Research.

Dickinson, L. (1994). Learner autonomy: what, how and why? Autonomy in Language Learning (1st ed.), (pp. 2-12). Porto Alegre : Universidade Federal do Rio Grande do Sul.

Hořínek, M. (2007). A closer look at learner autonomy - a qualitative study. Extended abstract of Diploma thesis. Retrieved August 2. Retrieved from http://is.muni.cz/th/12319/ff_m/thesis.pdf.

Kavaliauskiene, G. (2002). Three Activities to Promote Learner's Autonomy. The Internet TESL Journal, VIII, (7). Retrieved July 4. Retrieved from http://iteslj.org/Techniques/Kavaliauskiene-Autonomy/.

Little, D. (1996). Constructing a theory of learner autonomy: Some steps along the way. Retrieved August 27. Retrieved from http://archive. ecml.at/mtp2/ELP_TT/ELP_TT_CDROM/DM_layout/Reference $\%$ 20Materials/English/David \% 20Little \% 20Constructing $\% 20 a \% 20$ Theory $\%$ 20of $\%$ 20Learner $\%$ 20Autonomy.pdf.

Little, D. (2006). Learner autonomy: Drawing together the threads of self-assessment, goal-setting and reflection. Retrieved August 27.

(c) Ivashkevych Eduard, Onufriieva Liana

DOI (article): https://doi.org/10.32626/2227-6246.2021-51.09-32 
DOI: https://doi.org/10.32626/2227-6246.2021-51 2021. випуск 51

Retrieved from http://archive.ecml.at/mtp2/ELP_TT/results/DM_ layout/00_10/06/06Supplementarytext.pdf.

Mykhalchuk, Nataliia, \& Ivashkevych, Eduard (2018). Psycholinguistic features of the development of social intelligence of the teacher. Psykholinhvistyka. Psikholingvistika. Psycholinguistics: Zb. nauk. prats DVNZ «Pereiaslav-Khmelnytskyi ped. un-t imeni Hryhoriia Skovorody» - Psycholinguistics. Psycholinguistics. Psycholinguistics: Collection of Scientific Papers of Pereiaslav-Khmelnytskyi Hryhorii Skovoroda Pedagogical University, 23 (1), 242-257. Pereiaslav-Khmelnytskyi : FOP Dombrovska Ya. M. DOI https://doi.org/10.5281/ zenodo.1211618 (ISSN 2415-3397, Index Copernicus, Web of Science).

Mykhalchuk, Nataliia, \& Kryshevych, Olha (2019). The peculiarities of the perception and understanding of Sonnets written by W. Shakespeare by the students of the Faculty of Foreign Languages. Psykholinhvistyka. Psikholingvistika. Psycholinguistics: Zb. nauk. prats DVNZ "Pereiaslav-Khmelnytskyi ped. un-t imeni Hryhoriia Skovorody" Psycholinguistics. Psycholinguistics. Psycholinguistics: Collection of Scientific Papers of Pereiaslav-Khmelnytskyi Hryhorii Skovoroda Pedagogical University, 26 (1), 265-285. Pereiaslav-Khmelnytskyi : FOP Dombrovska Ya. M. DOI 10.31470/2309-1797-2019-26-1-265285.

Nunan, D. (2003). Nine steps to learner autonomy. Retrieved June 20. Retrieved from http://www.andrasprak.su.se/polopoly_fs/1.84007. 1333707257!/menu/standard/file/200 3_11_Nunan_eng.pdf.

Івашкевич Едуард, Онуфрієва Ліана. Розвиток автономії студента засобами формування його соціального інтелекту

\section{АНОТАЦІЯ}

Мета статmі - охарактеризувати автономну поведінку студентів, окреслити студента як суб'єкта учіння, що дасть нам змогу запропонувати шляхи формування поведінки завдяки стимулюванню розвитку структурних компонентів соціального інтелекту студентів.

Для розв'язання поставлених у роботі завдань використано такі теоретичні методи дослідження: категоріальний, структурно-функціональний, аналіз, систематизація, моделювання, узагальнення. Також у дослідженні використано емпіричні методи, такі як констатувальне дослідження та формувальний експеримент.

C Ivashkevych Eduard, Onufriieva Liana

DOI (article): https://doi.org/10.32626/2227-6246.2021-51.09-32 
DOI: https://doi.org/10.32626/2227-6246.2021-51 2021. випуск 51

Результати дослідження. Ми вважаємо, що соціальний інтелект педагога вміщує когнітивний, емпатійний і мнемічний аспекти. У попередньому викладі теоретичного матеріалу більшу увагу було приділено мнемічному аспекту соціального інтелекту, тоді як емпатійний аспект, на нашу думку, є не менш важливим. Елементи (або скрипти, фрейми, концепти) емпатійного аспекту соціального інтелекту складають зміст конкретних усвідомлених педагогом образів реальності, які можуть бути і такими, що сприймаються безпосередньо, і такими, які виникають у спогадах й уяві особистості. Специфрічна функція емпатійного аспекту соціального інтелекту полягає в тому, що емпатійні фрейми, скрипти, концепти наділяють емоційністю продукти інтелектуальної діяльності, своєрідну картину світу, яка складається у суб'єкта в результаті роботи соціального інтелекту, внаслідок чого світ постає для нього як існуючий у метакогнітивній срері. Саме тому, на нашу думку, немає сенсу говорити про існування емоційного інтелекту, адже той смисл, який вкладається багатьма дослідниками в че поняття, зафіксований саме в емпатійному аспекті соціального інтелекту. Хоча емпатійний аспект соціального інтелекту не усвідомлюється педагогом, саме він, на нашу думку, забезпечує усвідомлення емоційно-експресивної й емпатійної сторін об'єктів і суб'єктів у міжособистісній взаємодії.

Ми вважаємо, що сочіальний інтелект, однозначно, включає декларативні й оперативні (процедурні) знання, які індивід застосовує в реальному житті для інтерпретації подій, створення планів і прогнозування як дій повсякденного життя, так і професійних ситуацій. Ці уявлення, особисті спогади і правила інтерпретації складають когнітивний аспект соціального інтелекту. Своєю чергою, мнемічний аспект заповнює набутий людиною досвід, тоді як емпатійні можливості суб'єкта спрямовані на актуалізацію механізмів антиципації у розв'язанні різних проблем соціального життя.

Висновки. Доведено, що когнітивний аспект соціального інтелекту включає в себе сукупність досить стійких знань, очінок, правил інтерпретації подій, поведінки людей, їх взаємовідносин тощо на основі срормованої системи інтерпретацій на мікроструктурному і макроструктурному рівнях. Мікроструктура когнітивного аспекту соціального інтелекту детермінується функціями останнього, а саме пізнавально-оцінною, від якої залежить грамотна обробка й оцінювання інформації, яку сприймає суб'єкт; прогностичною, на основі якої здійснюється планування та про-

(C) Ivashkevych Eduard, Onufriieva Liana DOI (article): https://doi.org/10.32626/2227-6246.2021-51.09-32 
гнозування розвитку міжособистісних взаємодій; комунікативною, що забезпечує ефрективність власне процесу спілкування (ия функція пов'язана з адекватним сприйняттям і розумінням партнера по спілкуванню); рефлексивною, яка знаходить своє відображення безпосередньо в самопізнанні. Своєю чергою, макроструктура когнітивного аспекту соціального інтелекту виявляється у ставленні індивіда до себе як до цінності, ціннісно-смисловій позиції до міжособистісних відносин, а також в актуалізації мотиваційно-ціннісних орієнтацій особистості, аксіологічного ставлення до професійної й інших видів діяльності. Шляхом розвитку автономії студента ми стимулювали становлення у нього когнітивного аспекту соціального інтелекту.

Ключові слова: автономія студента, автономна поведінка, соціальний інтелект, когнітивний аспект соціального інтелекту, мотиваційні орієнтації, ціннісні орієнтації, аксіологічне настановлення.

\section{Ивашкевич Эдуард, Онуфриева Лиана. Развитие автономии студента средствами формирования его социального интеллекта}

\section{АННОТАЦИЯ}

Цель статьи - охарактеризовать автономное поведение студентов, определить студента как субъекта обучения, что позволит нам предложить пути формирования автономного поведения личности благодаря стимулированию развития структурных компонентов социального интеллекта студентов.

Для решения поставленных в работе задач использованы следующие теоретические методы исследования: категориальный, структурно-функциональный, анализ, систематизация, моделирование, обобщение. Также в исследовании использованы эмпирические методы, такие как констатирующее исследование и формирующий эксперимент.

Результаты исследования. Мы считаем, что социальный интеллект педагога содержит когнитивный, эмпатийный и мнемический аспекты. В предыдущих наших публикациях большее внимание было уделено мнемическому аспекту социального интеллекта, тогда как эмпатийный аспект, по нашему мнению, является не менее важным. Элементы (или скрипты, фреймы, концепты) эмпатийного аспекта социального интеллекта составляют содержание конкретных осознанных педагогом образов реальности, которые могут быть такими, что вос(c) Ivashkevych Eduard, Onufriieva Liana

DOI (article): https://doi.org/10.32626/2227-6246.2021-51.09-32 
ISSN 2227-6246 (Print)

ISSN 2663-6956 (Online)

ПРОБЛЕМИ СУЧАСНОї ПСИХОЛОГІї

DOI: https://doi.org/10.32626/2227-6246.2021-51

2021. випуск 51

принимаются непосредственно, а также и такими, которые возникают в воспоминаниях и воображении личности. Специфическая функция эмпатийного аспекта социального интеллекта заключается в том, что эмпатийные фреймы, скрипты, концепты наделяют эмоциональностью продукты интеллектуальной деятельности, создавая, таким образом, своеобразную картину мира, которая складывается в воображении субъекта в результате актуализации социального интеллекта, в результате чего мир становится для субъекта таковым, который существует исключительно в метакогнитивной срере. Именно поэтому, по нашему мнению, не имеет смысла говорить о существовании эмоционального интеллекта, ведь тот смысл, который вкладывается многими исследователями в данное понятие, зафиксирован именно в эмпатийном аспекте социального интеллекта. Хотя эмпатийный аспект социального интеллекта не до конца осознается педагогом, именно он, по нашему мнению, обеспечивает осознание эмоционально-экспрессивной и эмпатийной сторон объектов и субъектов в межличностном взаимодействии.

Мы считаем, что социальный интеллект, однозначно, включает декларативные и оперативные (процедурные) знания, которые индивид применяет в реальной жизни для интерпретации событий, создания планов и прогнозирования как действий повседневной жизни, так и профессиональных ситуаций. Эти представления, личные воспоминания и правила интерпретации составляют когнитивный аспект социального интеллекта. В свою очередь, мнемический аспект заполняет приобретенный человеком опыт, тогда как эмпатийный создает предпосылки, благодаря которым возможности субъекта направляются на актуализацию механизмов антиципации в решении различных проблем социальной жизни.

Выводы. Доказано, что когнитивный аспект социального интеллекта включает в себя совокупность достаточно устойчивых знаний, оценок, правил интерпретации событий, поведения людей, их взаимоотношений на основе сложившейся системы интерпретаций на микроструктурном и макроструктурном уровнях. Микроструктура когнитивного аспекта социального интеллекта детерминируется функциями последнего, а именно познавательно-оценочной, от которой зависит грамотная переработка и оценка информации, которую воспринимает субъект; прогностической, с учетом которой осуществляется плани-

(c) Ivashkevych Eduard, Onufriieva Liana DOI (article): https://doi.org/10.32626/2227-6246.2021-51.09-32 
DOI: https://doi.org/10.32626/2227-6246.2021-51 2021. виПУСК 51

рование и прогнозирование развития межличностных взаимодействий; коммуникативной, которая обеспечивает эффективность собственно процесса общения (данная функция связана с адекватным восприятием и пониманием партнера по коммуникации); рефлексивной, которая находит свое отражение непосредственно в самопознании. В свою очередь, макроструктура когнитивного аспекта социального интеллекта проявляется в отношении индивида к себе как к ценности, с учетом ценностно-смысловой позиции личности в межличностных отношениях, а также в актуализации мотивационно-ценностных ориентаций личности, аксиологического отношения к профессиональной и другим видам деятельности. Таким образом, посредством развития автономии студента мы стимулировали развитие когнитивного аспекта социального интеллекта.

Ключевые слова: автономия студента, автономное поведение, социальный интеллект, когнитивный аспект социального интеллекта, мотивационные ориентации, ценностные ориентации, аксиологическая установка.

Original manuscript received January 03, 2021

Revised manuscript accepted February 12, 2021

C Ivashkevych Eduard, Onufriieva Liana

DOI (article): https://doi.org/10.32626/2227-6246.2021-51.09-32 http://journals.uran.ua/index.php/2227-6246 